\title{
Finishing lambs using an integral feed under a restricted-feeding program in an intensive production system in Northern Mexico
}

\author{
Karla Rodríguez-Hernández ${ }^{\mathrm{a}}$, Jorge A. Maldonado-Jáquez ${ }^{\mathrm{a}}$, Lorenzo D. Granados-Rivera ${ }^{\mathrm{b}}$, \\ Juan I. Sánchez-Duartea , Pablo A. Domínguez-Martínez ${ }^{\mathrm{c}}$, Glafiro Torres-Hernández ${ }^{\mathrm{d}}$, \\ Emanuel A. Argüelles-Verdugo ${ }^{\mathrm{e}}$
}

\begin{abstract}
The objective of this study was to compare the productive performance of finishing lambs using an integral diet under a restricted-feeding program. Ten Dorper lambs were assigned to two homogenous groups according to live weight and age under a complete randomised block design. Group 1 was fed a traditional diet commonly used by the producer and group 2 was fed an integral feed restricted to $75 \%$ of dry matter requirement of lambs. The evaluated variables were: dry matter intake, initial and final live weight, daily weight gain, feed efficiency and body growth expressed in height, body length, thoracic diameter, cane length and cane width. A partial cost analysis was carried out to evaluate the economic viability. Lambs fed with the integral feed had better feed efficiency, higher dry matter intake, daily weight gain, height, body length and thoracic diameter when compared with the lambs fed the traditional diet. The use of an integral feed under a restricted-feeding program reduced the cost of finishing lambs by 2.46 dollars per head and finishing length by 120 days. Overall, providing an integral feed under a restricted-feeding program is a viable alternative for improving finishing lambs under intensive conditions in the Northern Mexico.

Key words: restricted-feeding, economic profitability, Dorper lambs.
\end{abstract}

\section{INTRODUCTION}

It is important that animals show adequate development to achieve a successful lamb fattening (Bernes et al 2012). In intensive production systems, this is accomplished by using total mixed rations (TMR) that meet the protein and energy requirements of the lambs (Atwood et al 2006). The use of TMR ensures a uniform ruminal fermentation because a constant level of concentrate is maintained, which together with an appropriate fiber content, stimulates chewing and saliva production, minimising losses by fermentation and ensuring a better utilisation of ammonia (Varga and Kolver 1997, Van Ackeren et al 2009). However, TMR require time and specialised equipment (mixer wagon, tractor, among others), which makes the adoption of this technology difficult for small producers (Bretschneider et al 2015). Therefore, an option that includes the benefits of the TMR is the preparation of an integral feed equivalent to a TMR but using dry ingredients, which can be stored in sacks to be used at the time required without the need of major equipment (Maldonado-Jáquez et al 2017).

Received: 19.02.2019.

Accepted: 02.08.2019.

${ }^{a}$ Campo Experimental La Laguna, Instituto Nacional de Investigaciones Forestales, Agrícolas y Pecuarias, Coahuila, México.

${ }^{b}$ Campo Experimental General Terán, Instituto Nacional de Investigaciones Forestales, Agrícolas y Pecuarias, Nuevo León, México.

${ }^{\mathrm{C} C a m p o}$ Experimental Valle del Guadiana, Instituto Nacional de Investigaciones Forestales, Agrícolas y Pecuarias, Durango, México.

dPrograma de Ganadería, Colegio de Postgraduados, Montecillo, México.

eDepartamento de Postgrado, Facultad de Agronomía y Zootecnia, Universidad Juárez del Estado de Durango, Durango, México.

*Corresponding author: LD Granados-Rivera; General Terán, Nuevo León, C.P. 67400, México; granados.danilo@inifap.gob.mx
Additionally, in the intensive production systems, feed is one of the factors which increases costs when considering the combination of high feed consumption and the price of the feedstuffs (dos Reis et al 2001, Bosa et al 2012). In order to reduce production costs, it is possible to resort to restricted-feeding programs, which consist of offering high-energy diets in restricted amounts of dry matter (Loerch 1990). This type of feeding program was originally designed for the beef industry; however, it also has been used for feeding replacement dairy heifers (Rodríguez-Hernández 2018). In dairy cattle, the restriction of dry matter is based on a percentage of live weight and can be as low as $1.5 \%$ or as high as $2.65 \%$ (Zanton and Heinrichs 2008, Lawrence et al 2016, Manthey and Anderson 2018).

For the specific case of lambs, information regarding the use of restricted feeding schemes is limited, particularly in intensive production systems of arid and semi-arid regions of northern Mexico, where information on nutrition and feeding of sheep is minimal (MedaAlducin et al 2011). Therefore, the use of an integral feed in combination with a restricted-feeding program could be an economically viable option for lamb finishing particularly in the arid and semi-arid regions. The aim of this study was to evaluate the productive behaviour of finishing Dorper lambs using an integral feed offered in a restricted manner, under intensive conditions in the Comarca Lagunera of Northern Mexico.

\section{MATERIAL AND METHODS}

The management of the animals used in this study was strictly adhered to the accepted guidelines for the ethical use, care and welfare of animals used for international research 
according to the Federation of Animal Science Societies ${ }^{1}$ and the National Academy of Medicine (NAM 2002).

The study was conducted in a production unit of the communal farm (ejido) La Goma, Lerdo, Dgo., Mexico, located in the Comarca Lagunera (24 $22^{\prime}$ ' and $26^{\circ} 23^{\prime} \mathrm{N}$ Latitude, $102^{\circ} 22^{\prime}$ ' and $104^{\circ} 47^{\prime}$ W Longitude, 1100 m.a.s.l.). This region has a desert climate corresponding to BWhw of Köppen classification (García 1988), characterised for being very dry or arid, semi-warm with cool winter, average annual precipitation of $240 \mathrm{~mm}$, and an average annual temperature of $25^{\circ} \mathrm{C}$, with ranges of $-1{ }^{\circ} \mathrm{C}$ in winter to $44{ }^{\circ} \mathrm{C}$ in summer.

Ten Dorper lambs were blocked by initial body weight (BW) and age, and then randomly assigned to one of two experimental diets under a complete randomised block design. Experimental diets consisted of 1) traditional diet $(\mathrm{n}=5 ; \mathrm{BW}$ of $18.9 \pm 1.8 \mathrm{~kg}$ and $95 \pm 6.8$ days of age $)$, which was used daily by the producer and was composed for $75 \%$ of corn silage and $25 \%$ of mixed forages hay and 2) integral feed $(\mathrm{n}=5$; $\mathrm{BW}$ of $18.7 \pm 5.7 \mathrm{~kg}$ and $97 \pm 3.8$ days of age) that consisted of a TMR that was prepared in a unique occasion in the facilities of the Experimental Station La Laguna of the INIFAP, located in Matamoros, Coahuila, Mexico. To elaborate TMR of integral feed, alfalfa hay and corn stover were chopped in a hammer mill grinder with a sieve of $1 \mathrm{~cm}$ of diameter, which was modified by adding along the sieve two central lines of 7 holes each with $5 \mathrm{~cm}$ of diameter. Subsequently, to prepare $800 \mathrm{~kg}$ of integral feed all the ingredients were weighed individually (forages and concentrates). All the ingredients were mixed using a spinning top type concrete mixer of 120 liters. The grain mix was prepared by first adding the ingredients in the following order: 2 parts of corn grain, 2 parts of sorghum grain, 1 part of soybean meal, 2 parts of bran, urea, minerals, and molasses which were mixed for 5 minutes at a speed between 28 to $32 \mathrm{rpm}$. The operation was repeated until all the concentrated ingredients were mixed. Subsequently, the forages were mixed with the grain mix by adding 2 parts of forages and 1 part of grain mix repeatedly until the mixer content was near three quarters full and allowed to mix for 3 more minutes, then the mixer was emptied and the operation was repeated until all the forages were mixed with the grain mix. Subsequently, the integral feed was placed in sacks with a capacity of $500 \mathrm{~kg}$ and transported to the production unit where the study was conducted.

The lambs were kept in individual $2 \times 3 \mathrm{~m}$ pens, with shading, feeding troughs, and drinking water ad libitum. The initial amount of traditional diet was established according to the producer's feeding system, which theoretically should cover $100 \%$ of the dry matter requirements of the lambs.

1 FASS, Federation of Animal Science Societies. 2010. Guide for de care and use of agricultural animal an agricultural research and leaching. Available at: http://www.fass.org/docs/agguide3rd/ Ag_Guide_3rd_ed.pdf (Accessed 15.08.2017).
The integral feed contained $40 \%$ forages (alfalfa hay and corn stover) and 60\% grain mix (Maldonado-Jáquez et al 2017). The initial quantity of integral feed offered was restricted to $75 \%$ of the dry matter intake recommendations of the National Research Council (NRC 1985) for early weaned lambs of $20 \mathrm{~kg} \mathrm{BW}$, which is $5 \%$ of BW then we multiplied it for $75 \%$ which expressed in percentage of BW is equivalent to $3.7 \%$. The amount of ration offered was increased by $20 \%$ for both diets when rejection was less than $10 \%$ of total offered. The feed intake was calculated daily by the difference between the amount of feed offered and the rejected feed.

The nutritional composition of corn silage and the forages mixture in the traditional diet is shown in table 1.

The components and nutritional quality of the traditional diet and the integral feed are shown in table 2. Feed was delivered daily at 7:00, 13:00 and 18:00 h for both groups. Fifty percent of the ration was offered on the first feeding time, and $25 \%$ in each of the subsequent feeding times. All the lambs had ad libitum access to fresh and clean water.

The variables analysed in this study were: dry matter intake (DMI), Initial BW, final BW, average daily weight gain (ADG), and feed efficiency. In addition, the growth of the animals was evaluated through body measurements of height, body length, thoracic diameter, cane length and width. Data collection was performed weekly during 9 weeks. The lambs were weighed using a hook-type electronic commercial scale with a capacity of $45 \mathrm{~kg} \pm 5 \mathrm{~g}$ (Metrology, Nuevo Leon, Mexico). A soft tape (Selanusa, Mexico City, Mexico) was used to determine body measurements, and a mechanical vernier (PRETUL, Mexico City, Mexico) was used to measure the cane width. The ADG was calculated by subtracting the initial BW from the final BW and dividing it between the test days. Feed efficiency was calculated dividing total weight gain between total feed consumption.

The information was analysed using the PROC MIXED of SAS version 9.4 (SAS Institute, 2013). The initial BW was used as a covariate for BW and ADG. To determine

Table 1. Nutritional composition of diet components used in the traditional diet for finishing Dorper lambs.

\begin{tabular}{|c|c|c|}
\hline Nutrient ${ }^{(1)}$ & Corn silage & Forages mix hay \\
\hline $\mathrm{DM}, \%$ of silage and mix & 30.70 & 93.14 \\
\hline $\mathrm{CP}$ & 10.47 & 14.13 \\
\hline NDF & 52.77 & 55.44 \\
\hline $\mathrm{ADF}$ & 32.99 & 36.77 \\
\hline TDN & 59.59 & 60.78 \\
\hline $\mathrm{NE}_{\mathrm{m}}, \mathrm{MJ} \mathrm{kg}^{-1} \mathrm{DM}$ & 5.61 & 5.90 \\
\hline $\mathrm{NE}_{\mathrm{g}}, \mathrm{MJ} \mathrm{kg}^{-1} \mathrm{DM}$ & 3.22 & 3.43 \\
\hline
\end{tabular}

${ }^{(1)}$ Expressed as percentage of the dry matter (DM) unless otherwise is indicated; $\mathrm{CP}=$ crude protein; $\mathrm{NDF}=$ neutral detergent fiber; $\mathrm{FDA}=$ acid detergent fiber; $\mathrm{TDN}=$ total digestible nutrients; $\mathrm{NE}_{\mathrm{m}}=$ net energy for maintenance; $\mathrm{NE}_{\mathrm{g}}=$ net energy for gain. 
the most appropriate covariance structure for each variable the Schwartz's Bayesian and Akaike criterions were used. When appropriate, the comparison of least squares means was made through the adjusted Tukey test. The general structure of the model was: $\mathrm{Y}_{\mathrm{ijkl}}=\mu+\mathrm{T}_{\mathrm{i}}+\mathrm{R}_{\mathrm{j}(\mathrm{i})}+\mathrm{S}_{\mathrm{k}}+\left(\mathrm{S}_{\mathrm{k}} \times \mathrm{T}_{\mathrm{j}}\right)$

Table 2. Ingredients and nutritional composition of diets used for feeding finishing Dorper lambs.

\begin{tabular}{|c|c|c|}
\hline Item $^{(1)}$ & Traditional diet & Integral feed \\
\hline \multicolumn{3}{|l|}{ Ingredient } \\
\hline Corn silage & 75.0 & - \\
\hline Alfalfa hay & 15.0 & 32.0 \\
\hline Oat hay & 7.0 & - \\
\hline Triticale hay & 3.0 & - \\
\hline Corn stover & - & 8.0 \\
\hline Corn grain & - & 17.1 \\
\hline Sorghum grain & - & 17.1 \\
\hline Wheat bran & - & 9.0 \\
\hline Soybean meal & - & 9.0 \\
\hline Urea & - & 1.2 \\
\hline Molasses & - & 4.8 \\
\hline Mineral pre-mix ${ }^{(2)}$ & - & 1.8 \\
\hline \multicolumn{3}{|l|}{ Nutrient } \\
\hline $\mathrm{DM}, \%$ of diet and feed & 61.92 & 93.34 \\
\hline $\mathrm{CP}$ & 14.13 & 20.18 \\
\hline FDN & 55.44 & 32.77 \\
\hline FDA & 36.77 & 19.28 \\
\hline TDN & 60.78 & 76.30 \\
\hline $\mathrm{NE}_{\mathrm{m}}, \mathrm{MJ} \mathrm{kg}^{-1} \mathrm{DM}$ & 5.90 & 8.12 \\
\hline $\mathrm{NE}_{\mathrm{g}}, \mathrm{MJ} \mathrm{kg}^{-1} \mathrm{DM}$ & 3.43 & 5.40 \\
\hline
\end{tabular}

${ }^{(1)}$ Expressed as a percentage of the dry matter (DM) unless otherwise is indicated; $\mathrm{CP}=$ crude protein; $\mathrm{NDF}=$ neutral detergent fiber; $\mathrm{FDA}=$ acid detergent fiber; $\mathrm{TDN}=$ total digestible nutrients; $\mathrm{NE}_{\mathrm{m}}=$ net energy for maintenance; $\mathrm{NE}_{\mathrm{g}}=$ net energy for gain. ${ }^{(2)}$ Mineral premix Ovi3ways group BIOTECAP.
$+\beta\left(X_{\mathrm{ijkl}}-\mathrm{X} \ldots\right)+\mathrm{E}_{\mathrm{ijkl}}$; where: $\mathrm{Y}_{\mathrm{ijkl}}=$ dependent variable; $\mu=$ constant that characterises the population, $T_{i}=$ fixed effect of the $\mathrm{i}$-th block (treatment) $(\mathrm{j}=1,2), \mathrm{R}_{\mathrm{j}(\mathrm{i})}=$ random effect of the $\mathrm{i}$-th repetition (animal) nested in the $\mathrm{j}$-th treatment $(\mathrm{i}=1,2,3,4,5), \mathrm{S}_{\mathrm{k}}=$ random effect of the $\mathrm{k}$-th week of treatment, $\mathrm{S}_{\mathrm{k}} \times \mathrm{T}_{\mathrm{i}}=$ effect of the treatment $\times$ time interaction; $X=$ effect of the covariate (initial weight), $\beta=$ regression coefficient associated with the covariate, $\mathrm{E}_{\mathrm{ijkl}}=$ random residual error. All random components were assumed to be normally distributed with zero mean and common variance. Dry matter intake and food efficiency data were analysed using the PROC GLM (SAS Institute 2013). The determination of relationships between body measurements with BW and ADG was made through the Pearson correlation analysis using the InfoStat v.2008 program (Balzarini et al 2008). Additionally, a partial cost analysis was performed to verify the feasibility of using the restricted-fed of the integral feed for finishing lambs. All the cost values were converted to US dollars.

\section{RESULTS}

Table 3 shows the effect of using the integral feed on the production and growth performance of lambs. Lambs fed the integral feed consumed $270 \mathrm{~g} \mathrm{~d}^{-1}$ of dry matter (DM) more than lambs receiving the traditional diet $(P<0.05)$. The initial BW was similar between treatments $(P>0.05)$, but the final BW was higher $(P<0.05)$ in lambs receiving integral feed than in the lambs fed the traditional diet. Therefore, the ADG of lambs fed the integral feed was $200 \mathrm{~g} \mathrm{~d}^{-1}$ more than the lambs fed the traditional diet. Considering ADG and DMI, a higher feeding efficiency $(P<0.05)$ was observed in lambs fed the integral feed compared with traditional diet fed lambs. Likewise, the lambs of the integral feed had better growth performance in terms of height, length and thoracic diameter. The average DMI expressed as a percentage of BW was $2.3 \%$ in lambs fed the traditional diet and $3.0 \%$ in lambs fed integral feed.

Table 3. Effect of feeding a traditional diet or an integral restricted-fed feed (mean \pm standard deviation) on the productive performance and growth of finishing Dorper lambs.

\begin{tabular}{|c|c|c|c|c|}
\hline Item $^{(1)}$ & Traditional diet & Integral feed & $\mathrm{EE}^{(2)}$ & Effect \\
\hline DMI, $\mathrm{g} \mathrm{d}^{-1}$ & $540 \pm 84.74$ & $811 \pm 62.15$ & 0.05 & $* * *$ \\
\hline Inicial BW, kg & $18.99 \pm 1.82$ & $18.78 \pm 5.73$ & 1.92 & NS \\
\hline Final BW, kg & $26.74 \pm 4.11$ & $38.30 \pm 9.47$ & 0.70 & $* * *$ \\
\hline ADG, $\mathrm{g} \mathrm{d}^{-1}$ & $120 \pm 32.67$ & $320 \pm 74.13$ & 0.02 & $* * *$ \\
\hline Feed efficiency & $0.180 \pm 0.03$ & $0.400 \pm 0.09$ & 0.03 & $* * *$ \\
\hline Height, $\mathrm{cm}$ & $50.74 \pm 16.48$ & $53.99 \pm 14.49$ & 0.39 & $* * *$ \\
\hline Length, $\mathrm{cm}$ & $51.48 \pm 7.49$ & $53.25 \pm 8.37$ & 0.51 & $*$ \\
\hline Thoracic diameter, $\mathrm{cm}$ & $60.55 \pm 20.37$ & $65.14 \pm 21.22$ & 0.53 & $* * *$ \\
\hline Cane length, $\mathrm{cm}$ & $12.46 \pm 4.31$ & $12.87 \pm 3.87$ & 0.45 & NS \\
\hline Cane width, $\mathrm{cm}$ & $3.85 \pm 0.46$ & $3.88 \pm 0.51$ & 0.34 & NS \\
\hline
\end{tabular}

${ }^{(1)} \mathrm{DMI}=$ dry matter intake; $\mathrm{BW}=$ body weight $\mathrm{ADG}=$ average daily weight gain; ${ }^{(2)} \mathrm{EE}=$ mean standard error; $\mathrm{NS}=$ non-significant. $*=P<0.05$; $* * *=P<0.0001 ;$ Feed efficiency $=$ total weight gain/total feed consumption. 
Treatment $\times$ time interaction was observed for BW, ADG and some growth performance variables. Lambs fed the integral feed had higher BW from week 6 until the end of the experiment, and had higher ADG in weeks 2 and 3, and from week 6 to 9 (figure $1, P<0.05$ ).

On the other hand, the height of lambs fed the integral feed was higher from week 5 compared to the lambs fed the traditional diet. Body length and thorax diameter were higher in lambs fed the integral feed in weeks 8 and 6 , respectively (figure $2, P<0.05$ ). No differences were observed for cane length and width between treatments during the experimental period $(P>0.05)$.

The correlation analysis between the growth performance variables indicated that most of the body measurements in lambs were positively correlated (table 4). Body weight was highly correlated $(P<0.0001)$ with ADG, height, body

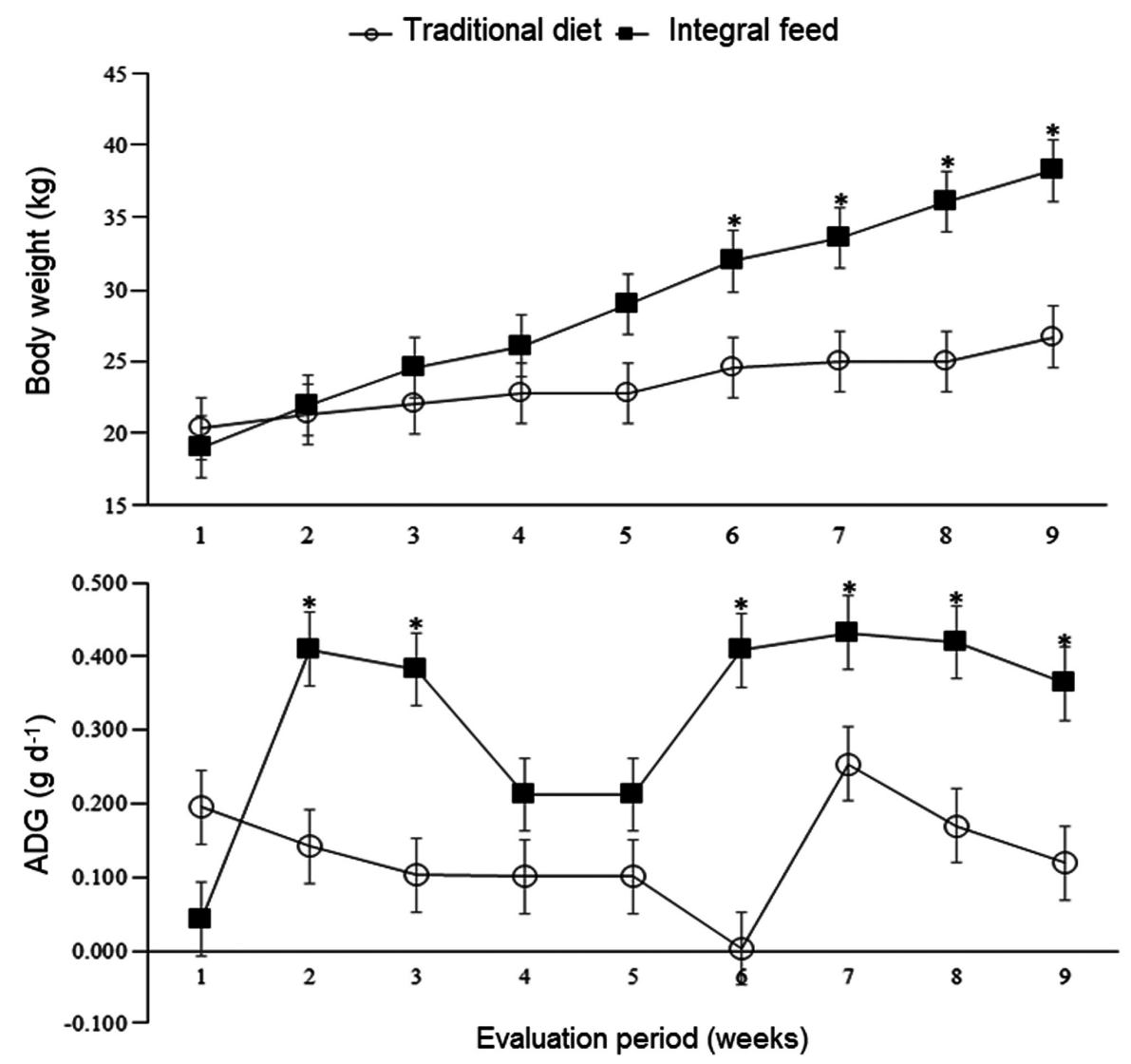

Figure 1. Treatment $\times$ time interaction effect on body weight and average daily gain of finishing Dorper lambs. $*=P<0.05$.

\section{$\rightarrow$ Traditional diet - Integral feed}

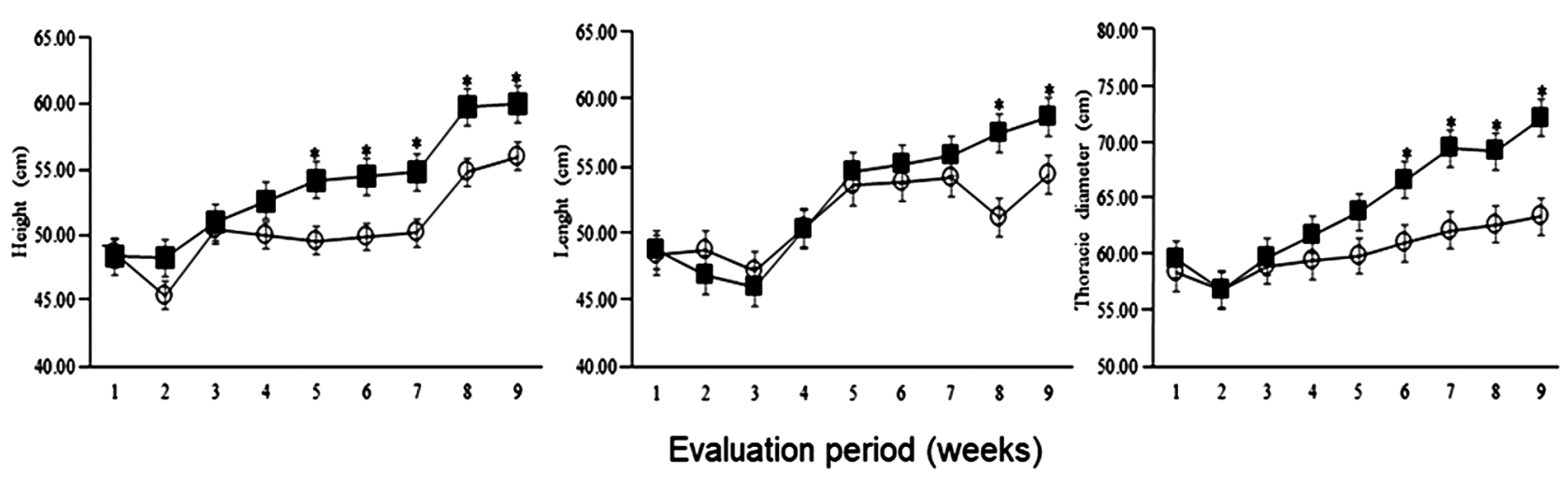

Figure 2. Treatment $\times$ time interaction effect on body growth of finishing Dorper lambs. $*=P<0.05$. 
Table 4. Correlation matrix for body growth in finishing Dorper lambs.

\begin{tabular}{|c|c|c|c|c|c|c|c|}
\hline & BW & ADG & Height & Body length & $\begin{array}{l}\text { Thoracic } \\
\text { diameter }\end{array}$ & Cane width & Cane length \\
\hline $\mathrm{BW}$ & 1.00 & $* * *$ & $* * *$ & $* * *$ & $* * *$ & $* * *$ & NS \\
\hline ADG & 0.41 & 1.00 & $* * *$ & $*$ & $* * *$ & NS & NS \\
\hline Height & 0.79 & 0.35 & 1.00 & $* * *$ & $* * *$ & $* * *$ & $* * *$ \\
\hline Body length & 0.78 & 0.22 & 0.66 & 1.00 & $* * *$ & $* * *$ & NS \\
\hline Thoracic diameter & 0.94 & 0.39 & 0.81 & 0.79 & 1.00 & $* * *$ & NS \\
\hline Cane width & 0.35 & 0.06 & 0.47 & 0.34 & 0.36 & 1.00 & $* * *$ \\
\hline Cane length & -0.12 & 0.005 & -0.32 & -0.17 & -0.13 & -0.92 & 1.00 \\
\hline
\end{tabular}

NS = Non-significant; $\mathrm{BW}=$ body weight; $\mathrm{ADG}=$ average daily weight gain; $*=P<0.05 ; * * *=P<0.0001$.

Table 5. Partial cost analysis of traditional diet and integral feed used for feeding finishing Dorper lambs.

\begin{tabular}{|c|c|c|c|c|}
\hline \multirow{2}{*}{ Ingredients } & \multicolumn{2}{|c|}{ Traditional diet } & \multicolumn{2}{|c|}{ Integral feed } \\
\hline & $\mathrm{g} \mathrm{kg}^{-1}$ & Dollars kg ${ }^{-1}$ & $\mathrm{~g} \mathrm{~kg}^{-1}$ & Dollars kg-1 \\
\hline Corn silage & 750 & 0.06 & - & - \\
\hline Alfalfa hay & 150 & 0.06 & 320 & 0.04 \\
\hline Oat hay & 70 & 0.03 & - & - \\
\hline Triticale hay & 30 & 0.01 & - & - \\
\hline Corn stover & - & - & 80 & 0.003 \\
\hline Corn grain & - & - & 171 & 0.04 \\
\hline Sorghum grain & - & - & 171 & 0.04 \\
\hline Wheat bran & - & - & 90 & 0.02 \\
\hline Soybean meal & - & - & 90 & 0.04 \\
\hline Urea & - & - & 12 & 0.004 \\
\hline Molasses & - & - & 48 & 0.007 \\
\hline Mineral Premix & - & - & 18 & 0.02 \\
\hline Total cost & - & 0.16 & - & 0.20 \\
\hline
\end{tabular}

Rate exchange price of 1 US dollar per 20.33 MXN (December 10, 2018).

length, thoracic diameter, and cane width. Similarly, ADG was correlated $(P<0.0001)$ with body height, thoracic diameter and body length. There was a correlation between height, body length and thoracic diameter $(P<0.0001)$. Cane width was only correlated with cane length $(P<0.0001)$.

DMI and ADG were considered for the analysis partial costs. Starting from the costs of each ingredient used, the cost per kg of diet used was determined (table 5). The cost per $\mathrm{kg}$ of integral feed was $\$ 0.20$ and for the traditional diet it was $\$ 0.16$. The feeding cost per day for lambs receiving integral feed was $\$ 0.19$. When considering ADG and the period of 70 days needed to obtain a final sale BW of $38.30 \mathrm{~kg}$ for lambs fed the integral feed therefore the total cost of fattening was $\$ 13.02$ per lamb. The feeding cost per lamb fed the traditional diet was $\$ 0.08$ per day; however, considering the ADG in this group, a fattening period of 190 days would be required to achieve a final sale BW similar to the lambs fed the integral feed. Therefore, the total cost of fattening lambs fed the traditional diet would be $\$ 15.55$.

\section{DISCUSSION}

The observed DMI expressed as a percentage of BW of the lambs fed the traditional diet was lower than that reported by other authors when a diet based on corn silage was used (2.8\% of BW, Nouel-Borges et al 2013), and the NRC (1985) recommendation for growing lambs is $5 \%$ of BW. Therefore, the $75 \%$ inclusion rate of corn silage on the traditional diet could limit the DMI of the lambs and subsequently affect feed efficiency (dos Reis et al 2001).

Additionally, there are reports indicating that the use of corn silage in lamb rations produces meat with a high proportion of fatty acids beneficial to human health (Sulliman et al 2016, Bernes et al 2012), as it is a feedstuff that provides high energy (Golmahi et al 2006). However, corn silage has low CP content, therefore nutritional requirements for optimum growth are difficult to meet even if this silage has a high nutritional quality, consequently observing an inadequate productive performance during fattening (da Silva-Dos Reis et al 2017, Grabowicz et al 
2013, Bernes et al 2012). Moreover, keep animals with high starch content diets increases the incidence of fat accumulation reducing consumer acceptability (Alhidary et al 2016).

The use of TMR in ruminants can improve efficiency and feed conversion through optimal ruminal fermentation, cholesterol metabolism, development of the gastrointestinal tract, improvement of weight gain (Zhong et al 2018). Additionally, a better feed efficiency and feed conversion has been observed in lambs fed a diet containing an adequate amount of fiber than those fed a low-fiber diet (Reséndiz et al 2013). Therefore, the lambs fed the integral feed, in spite of receiving only $75 \%$ of their DM requirements, had the highest BW gains. The ADG of lambs fed the integral feed were in the optimum range for lambs between 20 to $40 \mathrm{~kg}$ live weight (300-400 $\mathrm{g} \mathrm{d}^{-1}$; NRC 1985) which was probably the effect of a better DM digestibility. Steers fed with a TMR restricted to $30 \%$ of BW compared with steers fed a corn silage diet offered ad libitum, had better feeding efficiency and DM digestibility (Loerch 1990, Lee et al 2015). This may be due to the fact that when diets high in energy are used, a substantial increase in the DMI is observed (Cherif et al 2018), and when the energy level increases, as reported by Muhammad et al (2011), the DMI and the weight gain also increase. This could be observed in the lambs fed the integral feed in the present study, where the higher DMI and better ADG were the result of an adequate supply of energy and protein in the diet, which led to a more effective use of the nutrients contained in the food (Przemyslaw et al 2015), which is related to a better feeding efficiency (de Souza-Cardoso et al 2017). In adition, an amount of grains that is greater than that contained in a traditional diet made possible to have a greater synthesis of propionic acid, and with it a greater use of energy, which results in a greater amount of net energy for weight gain. It has been shown that in the fattening of lambs, the use of energy has a greater efficiency when it increases the proportion of propionic acid. Consequently, the increase in the molar proportion of propionic acid generates greater weight gain in lambs (Judson et al 1968).

Lambs fed integral feed in this study had a homogeneous body growth, showing better bone and muscle development than lambs fed the traditional diet. This is important, since a better body development is a key feature in meat animals and is directly related to the economic income (Kumar et al 2018). However, the information that describes the relationship between feeding and growth development in lambs is limited; it has been pointed out that BW gains are positively related to body growth measures in Kajli lambs (Iqbal et al 2014). Also, a positive relationship was observed among body growth variables with high correlation coefficients between the thorax circumference and BW (Afolayan et al 2006) which coincides with the observations made in the present study. In this sense, the determination of animal live weight, linear body measures, and their inter-relationships and correlation is imperative for determining genetic potential, breed standards, and improved breeding programs for higher meat production (Assan 2015).

Maximising the productive behaviour in animals and reducing the cost of production are two indicators that must be taken into account to achieve a successful feeding program (Ben-Salem and Smith 2008). The use of restricted-feeding of an integral feed in the present study positively influenced the productive parameters in the lambs and although the total cost per $\mathrm{kg}$ of integral feed was higher compared to the traditional diet, the productive performance of the lambs allowed to reduce the total cost of feeding in $\$ 2.46$ and the duration of the finishing phase in 120 days. The findings of this study agreed with the recommendations of previous studies (Hauss de Sousa et al 2012, Cirne et al 2013, Abbasi et al 2014) which reported that the use of diets with high energy and $\mathrm{CP}$ contents (between 16 and 20\%), allowed for better ADG, less fattening time, reducing the cost and maximising the economic profit.

The restricted-feeding program using an integral feed for finishing lambs under intensive management conditions in Northern Mexico represents a viable alternative, since it decreased to a greater extent the fattening time and represented considerable economic savings. The use of high inclusion rates of corn silage to feed lambs for finishing negatively affected the productive performance. Further studies on restricted-feeding of an integral feed are needed since the profitability of intensive farms in Northern Mexico constantly demands better feeding programs.

\section{REFERENCES}

Abbasi IM, Sahito HA, Abbasi F, Menghwar DR, Kaka NA, et al. 2014. Impact of different crude protein levels on growth of lambs under intensive management system. Int J Adv Res 2, 227-235.

Afolayan RA, Adeyinka IA, Lakpíni CAM. 2006. The estimation of live weight from body measurements in Yankasa sheep. Czech J Anim Sci 51, 343-348.

Alhidary IA, Abdelrahman MM, Alyemni AH, Khan RU, Al-Saiady MY, et al. 2016. Effect of alfalfa hay on growth performance, carcass characteristics, and meat quality of growing lambs with ad libitum access to total mixed rations. $R$ Bras Zootec 45,302-308.

Assan N. 2015. Prospects for utilization of the relationship between zoometrical measurements and performance traits for poultry and livestock genetic improvement in developing countries. Sci J Anim Sci 4, 124-132.

Atwood SB, Provenza FD, Villalba JJ, Weidmeier RD. 2006. Intake of lambs offered ad libitum access to one of three iso-caloric an iso-nitrogenous mixed rations or a choice of all three foods. Livest Sci 101,142-149.

Balzarini MG, González L, Tablada M, Casanoves F, Di Rienzo JA, et al. 2008. Manual del usuario. Editorial Brujas, Córdoba, Argentina.

Ben-Salem H, Smith MB. 2008. Feeding strategies to increase small ruminant production in dry environments. Small Rum Res 77, 174-194.

Bernes G, Turner T, Pickova J. 2012. Sheep fed only silage or silage supplemented with concentrates 2. Effects on lamb performance and fatty acid profile of ewe milk and lamb meat. Small Rum Res $102,114-124$. 
Bosa R, Faturi C, Rodrigues-Vascocelos HG, Moraes-Cardoso A, Oliveira-Ramos AF, et al. 2012. Intake and apparent digestibility with different inclusion levels of coconut meal for sheep feeding. Acta Scientiarum 34, 57-62.

Bretschneider G, Mattera J, Cuatrin A, Arias D, Wanzenried R. 2015. Effect of ensiling a total mixed ration on feed quality for cattle in smallholder dairy farms. Arch Med Vet 47, 225-229.

Cherif M, Ben-Salem H, Abidi S. 2018. Effect of the addition of Nigella sativa seeds to low of high concentrate diets on intake, digestion, blood metabolites, growth and carcass traits of Barbarine Lamb. Small Rum Res 158, 1-8.

Cirne LGA, Oliveira GJC, Jaeger SMPL, Bagaldo AR, Leite MCP, et al. 2013. Performance of feedlot lambs with exclusive concentrate diet with different percentages of protein. Arq Bras Med Vet 65, 262-266.

da silva-Dos Reis SD, Mauricio-Manarelli D, Previdelli-Orrico MA, Chiare-Alves D, De Sousa-Cunha S. 2017. Nutrient intake by lambs fed corn, saccharin sorghum and forage sorghum silages. 54 Reunión de la Sociedad Brasileira de Zootecnia, 24 al 28 de Julio, Foz do Igacu, Brasil, Pp 1140.

de Souza-Cardoso E, Almeida de Santana H, Prates de Oliveira A, Carvalho de Ferreira H, Fernandes de Oliveira Z, et al. 2017. Correlation between performance and feeding behavior of feedlot lambs fed without roughage diet. Acta Scientiarum 39, 169-173.

dos Reis W, Cabreira-Jobim C, Fonseca-Macedo FA, Nunes-Martins E, Cecato U, et al. 2001. Performance of feedlot lambs fed high-moisture grain corn silage or reconstituted grain corn silage in replacement of dry grain in the diet. Rev Bras Zootec 30, 596-603.

García E. 1998. Modificaciones al sistema de clasificación climática de Köppen. Universidad Nacional Autónoma de México, D.F., México.

Golmahi A, Haghighian-Roodsary M, Gholaminia AH, Hill J. 2006. The replacement of maize silage by urea-treated whole-crop barley in the diets of Iranian native sheep. Small Rum Res 64, 67-76.

Grabowicz M, Zaremba I, Szterk P, Dorszewski P. 2013. Effect of sorghum silage on performance of fattening lambs. In: Dorszewski P, Grabowicz M, Szterk P, Zaremba I (eds). Procceedings of XLII Scientific Conference CAN CAS PAS, Bydgoszcz, Poland, 117-118.

Hauss de Sousa W, Queiroga-Cartaxo F, Germano-Costa R, Fontes-Cezar M, Gomes-Cunha M, et al. 2012. Biological and economic performance of feedlot feeding on diets with different energy densities. Rev Bras Zootec 41, 1295-1291.

Iqbal ZM, Javed K, Abdullah M, Ahmad N, Ali A, et al. 2014. Estimation of body weight from different morphometric measurements in Kajli lambs. J Anim Plant Sci 24, 700-7003.

Judson GJ, Anderson E, Luick JR, Leng RA. 1968. The contribution of propionate to glucose synthesis in sheep given diets of different grain content. Brit J Nutr 22, 69-75.

Kumar S, Dahiya SP, Malik ZS, Patil CS. 2018. Prediction of body weight from linear body measurements in sheep. Indian J Anim Sci 52, 1263-1266.

Lawrence RD, Anderson JL, Clapper JA. 2016. Evaluation of camelina meal as a feedstuff for growing dairy heifers. J Dairy Sci 99, 6215-6228.

Lee SJ, Kin DH, Guan Le Lou, Ahn, SK, Cho KW, et al. 2015. Effect of medicinal plant by-products supplementation to total mixed ration on growth performance, carcass characteristics and economic efficacy in the late fattening period of Hanwoo steers. Asian Australas J Anim Sci 28, 1729-1735.
Loerch SC. 1990. Effects of feeding growing cattle high-concentrate diets at a restricted intake on feedlot performance. J Anim Sci 68, 3086-3095.

Maldonado-Jáquez JA, Granados-Rivera LD, Hernández-Mendo O, Pastor-López FJ, Isidro-Requejo LM, et al. 2017. Uso de un alimento integral como complemento a cabras locales en pastoreo: respuesta en producción y composición química de la leche. Nova Scientia 9, 55-75.

Manthey AK, Anderson JL. 2018. Growth performance, rumen fermentation, nutrient utilization, and metabolic profile of dairy heifer's limit-fed distillers dried grains with ad libitum forage. J Dairy Sci 101, 365-375.

Meda-Alducin P, Maldonado-Jáquez JA, Tovar-Luna I, Jaimes-Jaimes J. 2011. Efecto del nivel de proteína cruda en la ración sobre el comportamiento de corderos en finalización. Rev Chapingo ser zonas aridas 10, 61-66.

Muhammad N, Tukur HM, Maigandi SA, Daneji AI. 2011. Performance and cost of production of fattening Uda sheep diets containing different energy levels in a semi-arid environment. IJAAAR 1-2, 79-85.

NAM, National Academy of Medicine. 2002. Guide for the care and use of laboratory animals. National Academy of Medicine-Mexico and the Association for Assessment and Accreditation of Laboratory Animal Care International, NAM, México.

Nouel-Borges G, Figueroa J, Petit P, Sánchez-Blanco R. 2013. Preliminary evaluation of Sisal (Agave sisalana) silage on total confinement lamb feeding. Asian J Anim Res 1, 9-11.

NRC, National Research Council. 1985. Nutrient requirements of sheep. $6^{\text {th }}$ ed. Nation Research Council, National Academy Press, Washington, D.C., USA.

Przemyslaw S, Cezary P, Stanislaw M, Krzysztof L, Barbara P, et al. 2015. The effect of nutritional and fermentation characteristics of grass and legume silages on feed intake, growth performance and blood indices of lambs. Small Rum Res 123, 1-7.

Reséndiz CV, Hernández O, Guerrero I, Gallegos J, Martínez PA, et al. 2013. Fattening Pelibuey lambs fed with different alfalfa levels in the diet. Arch Zoot 62, 457-467.

Rodríguez-Hernandez K. 2018. Evaluation of carinata meal in dairy heifer feeding programs. Doctoral Dissertation, South Dakota State University, Brookings, USA.

SAS, Statistical Analysis System. 2013. SAS version 9.4. SAS Institute Inc., Cary, NC, USA.

Suliman AIA, Badr AMM, Ebtehag IM.2016. Performance of lambs fed on biologically treated silages. Int J Chemtech Res 9, 151-160.

Van Ackeren C, SteingaB H, Hartung K, Funk R, Drochner W. 2009. Effect of roughage level in a total mixed ration on feed intake, ruminal fermentation patterns and chewing activity of early-weaned calves with ad libitum access to grass hay. J Anim Feed Sci Tech 153, 48-59.

Varga GA, Kolver ES. 1997. Microbial and animal limitations to fiber digestion and utilization. J Nutr 127, 819S-823S.

Zanton GI, Heinrichs AJ. 2008. Rumen digestion and nutritional efficiency of dairy heifers' limit-fed a high forage ratio to four levels of dry matter intake. J Dairy Sci 91, 3579-3588.

Zhong RZ, Fang Y, Zhou DW, Sun XZ, Zhou CS, et al. 2018. Pelleted total mixed ration improves growth performance of fattening lambs. J Anim Feed Sci Tech 242,127-134. 
